\title{
The Basis of the Alkalophilic Property of a Species of Bacillus
}

\author{
By K. OHTA, A. KIYOMIYA, N. KOYA MA AND Y. NOSOH \\ Laboratory of Chemistry of Natural Products, Tokyo Institute of Technology, \\ Meguroku, Tokyo I52, Japan
}

(Received 9 July 1974; revised I2 September 1974)

\begin{abstract}
SUMMARY
An alkalophilic bacterium belonging to the genus Bacillus was isolated from an indigo ball. The bacterium exhibited a maximum growth rate at $\mathrm{pH}$ 10.0 to 10.5 . The incorporation of ${ }^{14} \mathrm{C}$-labelled amino acids or $\left[{ }^{14} \mathrm{C}\right]$ uracil, uptake of ${ }^{14} \mathrm{C}$-labelled $\alpha$ amino isobutyric acid into the bacterium and oxygen consumption of the bacterium with amino acids as substrates were all maximum at $\mathrm{pH} 9.0$ to 10.5 . The uptake of $\left[\mathrm{U}-{ }^{14} \mathrm{C}\right] \mathrm{glucose}$ into the organism and oxygen consumption with carbohydrates, on the other hand, showed little variation of rate in the $\mathrm{pH} 8$ to ro region. The oxygen consumption of intact bacteria or protoplasts in culture medium was maximum at $\mathrm{pH}$ I0. The membrane of the bacterium oxidized $\mathrm{NADH}$ maximally at $\mathrm{pH} 7.5$, and ATPase bound to the membrane exhibited maximum activity at $\mathrm{pH} 7$. L-Lactate, L-alanine and malate dehydrogenases in the soluble fraction exhibited maximum activities at $\mathrm{pH} 7 \cdot 4$ to $8 \cdot 4$. The alkalophilic property of the bacterium may be due to the behaviour of the membrane towards charged substances admitted into the organisms.
\end{abstract}

\section{INTRODUCTION}

Recently, many species of alkalophilic bacteria belonging to the genus Bacillus have been isolated (Horikoshi, I971 $a, b$, I972; Boyer \& Ingle, I972; Horikoshi \& Atsukawa, I973 $a, b$; Kurono \& Horikoshi, I973). These bacteria were found to prefer alkaline environments ( $\mathrm{pH}$ Io to I I) for their optimum growth. The authors cited above have purified various kinds of exoenzymes from the alkalophilic bacteria and examined the biochemical properties, especially those concerning the alkalophilicity and alkalostability, of the enzymes. No work on the alkalophilic properties or alkalostability of the bacteria, however, has yet been reported. In our laboratory an alkalophilic bacterium exhibiting a maximum growth rate at $\mathrm{pH} 10 \cdot 0$ to 10.5 was isolated from an indigo ball, which mainly consists of fermented indigo leaves and is used as a source of natural indigo dye. We report some biochemical properties concerning the alkalopilicity and alkalostability of the bacterium.

\section{METHODS}

Media. For isolation and maintenance of the organism, a medium of the following composition was used (g/1 deionized water): polypeptone, I0; meat extract, I0; yeast extract, 3; glucose, $3 ; \mathrm{Na}_{2} \mathrm{CO}_{3}$ (anhydrous), IO. Solid medium was prepared by the addition of $2 \%$ $(\mathrm{w} / \mathrm{v})$ agar. For culture, a medium of the following composition was used ( $\mathrm{g} / 1$ deionized water): polypeptone, IO; glucose, I0; yeast extract, I.5; $\mathrm{Na}_{2} \mathrm{PO}_{4} \cdot 12 \mathrm{H}_{2} \mathrm{O}, \mathrm{I} \cdot 5 ; \mathrm{NaCl}, \mathrm{I} \cdot 5$; $\mathrm{MgCl}_{2} \cdot 6 \mathrm{H}_{2} \mathrm{O}, 0 . \mathrm{I} ; 3 \mathrm{M}-\mathrm{NaOH}, \mathrm{I} 2.5 \mathrm{ml}$. The $\mathrm{Na}_{2} \mathrm{CO}_{3}$ or $\mathrm{NaOH}$ and the solution containing the other components were separately sterilized and mixed before incubaton. The $\mathrm{pH}$ values of the media were $10 \cdot 0$ to 10.5 .

Isolation. The indigo ball used as the source of the isolate was kindly given by $\mathrm{Mr} \mathrm{H}$. Ichimura, Ibaragi Prefecture, Japan. The material was inoculated into the isolation medium 
and incubated at $37^{\circ} \mathrm{C}$ with shaking, the $\mathrm{pH}$ value being kept at io to I I with $3 \mathrm{M}-\mathrm{NaOH}$ during the incubation. After 2 days, the culture was streaked on the solid medium. After repeated transfer and plating-out on the solid medium at $37^{\circ} \mathrm{C}$, two different kinds of culture were obtained. One was able to grow well even at $\mathrm{pH} 7$ to 8 , while the other grew poorly. The latter culture was used in the present study.

Identification. The isolate was identified according to the methods described by Smith, Gordon \& Clark (1952) and in Bergey's Manual of Determinative Bacteriology (1957).

Culture. The organisms from a fresh culture on solid medium $\left(37^{\circ} \mathrm{C}, 16 \mathrm{~h}\right.$ ) were inoculated in the culture medium ( $500 \mathrm{ml}$ ), and incubated at $37^{\circ} \mathrm{C}$ with shaking, the $\mathrm{pH}$ being kept at 10.0 to 10.5 with $3 \mathrm{M}-\mathrm{NaOH}$. The organisms in an early stationary phase ( 5 to $9 \mathrm{~h}$ ) were collected by centrifuging, washed with $0.1 \mathrm{M}$-phosphate buffer $(\mathrm{pH} 7.5)$ containing $0.9 \%$ $(\mathrm{w} / \mathrm{v}) \mathrm{NaCl}$, and suspended in the buffer.

Protoplast, extract and the membrane and soluble fraction of the isolate. The organisms in early stationary phase were suspended in $20 \mathrm{mM}$-phosphate buffer $(\mathrm{pH} 7 \cdot 3)$ containing Io $\mathrm{mM}-\mathrm{MgCl}_{2}$ and $0.3 \mathrm{M}$-sucrose $\left(E_{650}=50\right.$; a suspension of $E_{650}=$ Io contained $5.5 \mathrm{mg}$ dry wt organisms $/ \mathrm{ml}$ ). The suspension was treated with lysozyme (EC. 3.2.1 . $17 ; 50 \mu \mathrm{g} / \mathrm{ml}$ ) at $30{ }^{\circ} \mathrm{C}$ for $10 \mathrm{~min}$, and centrifuged at $5000 \mathrm{~g}$ for $\mathrm{I} 0 \mathrm{~min}$. The precipitate (protoplast) was washed with the buffer and suspended in the buffer (half the volume used to prepare the original suspension). The new suspension was used as the protoplast sample.

To the precipitate (protoplast) obtained as described above was added 20 mM-phosphate buffer ( $\mathrm{pH} 7.3$ ) containing $0.9 \%(\mathrm{w} / \mathrm{v}) \mathrm{NaCl}$ (about 15 times the volume of the precipitate) and then deoxyribonuclease I (EC. $3.1 .4 .5 ; 30 \mu \mathrm{g} / \mathrm{ml}$ ). The mixture was incubated at $30{ }^{\circ} \mathrm{C}$ for $30 \mathrm{~min}$ and centrifuged at $30000 \mathrm{~g}$ for $40 \mathrm{~min}$. The precipitate and supernatant liquid thus obtained were used as the membrane and soluble fractions, respectively. The precipitate was suspended in $20 \mathrm{mM}$-phosphate buffer $(\mathrm{pH} 7 \cdot 3)$ containing $0.9 \%(\mathrm{w} / \mathrm{v}) \mathrm{NaCl}$.

Base composition of deoxyribonucleic acid. DNA was isolated according to the procedure of Marmur (196I), and the guanine-cytosine (GC) content of the DNA was determined by the thermal denaturation method (Marmur \& Doty, 1962).

Oxygen consumption. The oxygen consumption of intact bacteria with or without glucose (or L-amino acids) was manometrically measured in a Warburg flask. To $2.0 \mathrm{ml}$ of the reaction mixture consisting of Io mM-phosphate buffer, $0.9 \%(\mathrm{w} / \mathrm{v}) \mathrm{NaCl}$ and $0.3 \%(\mathrm{w} / \mathrm{v})$ Casamino acids (or $0.1 \mathrm{M}$-carbohydrates or $30 \mathrm{mM}$-L-amino acids) was added $0.2 \mathrm{ml}$ of the suspended bacteria $\left(E_{650}=13\right)$. The $\mathrm{pH}$ value of the reaction mixture was previously adjusted with $3 \mathrm{M}-\mathrm{NaOH}$ to give a desired value when mixed with the suspension.

The oxygen consumption of protoplasts in the culture medium, or of extract with carbohydrates or amino acids as substrates, or of the membrane fraction with NADH as substrate, was measured at $37^{\circ} \mathrm{C}$ using a Clark-type oxygen electrode. To $6.0 \mathrm{ml}$ of the culture medium containing $0.2 \mathrm{M}$-sucrose was added $0.5 \mathrm{ml}$ of the protoplast sample. To $6.0 \mathrm{ml}$ of the reaction mixture, consisting of ro mM-phosphate buffer, $0.9 \%$ (w/v) $\mathrm{NaCl}$ and $10 \mathrm{mM}-$ carbohydrates, amino acids or $\mathrm{NADH}$, was added $0.5 \mathrm{ml}$ of the extract or membrane fraction. The final $\mathrm{pH}$ of the mixture was as indicated in the text.

Enzyme assays. L-Lactate, L-alanine and malate dehydrogenases (EC. I.I.I.27, EC. I.4.I.I and EC. I.I.I.37, respectively) were assayed according to the methods of Hakala, Glaid \& Schwert (1956), Wiame, Piérard \& Ramos (I962) and Ochoa (1955), respectively. The procedure of Nakao, Tashima, Nagano \& Nakao (1965) was used to assay ATPase (EC. 3.6.I.3).

Incorporation of amino acids into protein. The reaction mixture contained $0 \cdot 1 \mathrm{M}$-glucose, $0.04 \%(\mathrm{w} / \mathrm{v})$ Casamino acids, I $\mu \mathrm{Ci}$ of U-14. C-labelled Chlorella hydrolysate $(40 \cdot 3 \mathrm{mCi} / \mathrm{mg}$ - 
atom $\mathrm{C}$ ) and $0.9 \%(\mathrm{w} / \mathrm{v}) \mathrm{NaCl}$ in $0 . \mathrm{I} \mathrm{M}$-phosphate buffer of an appropriate $\mathrm{pH}$ value; $2 \cdot 0 \mathrm{ml}$ was pre-incubated at $37{ }^{\circ} \mathrm{C}$ for $3 \mathrm{~min}$. The reaction was started by adding $0.5 \mathrm{ml}$ of the bacterial suspension $\left(E_{650}=10\right)$, and terminated by adding $5 \mathrm{ml}$ of cold $10 \%(\mathrm{w} / \mathrm{v})$ trichloroacetic acid (TCA) containing $0.032 \%(\mathrm{w} / \mathrm{v})$ Casamino acids. The precipitates were dissolved in $0.5 \mathrm{ml}$ of I $\mathrm{M}-\mathrm{NaOH}$ containing I \% (w/v) thioglycolic acid. To the solution was added $5 \mathrm{ml}$ of $5 \%(\mathrm{w} / \mathrm{v}) \mathrm{TCA}$, and it was heated at $90{ }^{\circ} \mathrm{C}$ for $30 \mathrm{~min}$. The precipitates were washed once with $5 \%(\mathrm{w} / \mathrm{v}) \mathrm{TCA}$, twice with $5 \mathrm{ml}$ acetone and twice with $5 \mathrm{ml}$ ethanol, and were dissolved in a mixture of $0.2 \mathrm{ml}$ of $\mathrm{I} \mathrm{M}-\mathrm{NaOH}$ and $\mathrm{I} 5 \mathrm{ml}$ of the scintillation fluid $[4 \mathrm{~g} \mathrm{2,5-}$ diphenyloxazole (PPO), $0 . \mathrm{I} g$ I,4-bis(2-(5-phenyloxazolyl))-benzene (POPOP) in $\mathrm{I} 1$ of a mixture of $70 \%(\mathrm{v} / \mathrm{v})$ toluene and $30 \%(\mathrm{v} / \mathrm{v})$ ethanol.] Radioactivity was measured in a Packard-Tris-Carb liquid scintillation spectrometer, model 3320.

Incorporation of uracil into nucleic acid. The procedure was essentially similar to that used for the incorporation of amino acids into protein, except that $\mathrm{I} \mu \mathrm{Ci}$ of ${ }^{\left[2-{ }^{14} \mathrm{C}\right] u r a c i l}$ $(21 \cdot 0 \mathrm{mCi} / \mathrm{mmol})$ was used in place of ${ }^{14} \mathrm{C}$-labelled Chlorella hydrolysate and Casamino acids. The reaction was terminated with $10 \%(\mathrm{w} / \mathrm{v})$ TCA. The precipitates were washed with TCA and organic solvents and dissolved in a mixture of $\mathrm{NaOH}$ and the scintillation fluid, as described in the amino acids incorporation experiments.

Uptake of $\alpha$-amino-isobutyric acid or glucose into bacteria. The reaction mixture used for the uptake experiments of $\alpha$-aminoisobutyric acid (AIB) or glucose contained $0 \cdot$ I M-glucose, Io $\mu \mathrm{M}$-AIB and $2 \mu \mathrm{Ci}$ of $\mathrm{I}^{-14} \mathrm{C}$-labelled $\mathrm{AIB}(4.84 \mathrm{mCi} / \mathrm{mmol})$ or $0.2 \mathrm{~mm}$-glucose and $0.4 \mu \mathrm{Ci}$ of [U-14 $\mathrm{C}]$ glucose $(5.0 \mathrm{mCi} / \mathrm{mmol})$, respectively, in $0.1 \mathrm{M}$-phosphate buffer containing $0.9 \%$ (w/v) $\mathrm{NaCl}$. To I.5 $\mathrm{ml}$ of the reaction mixture pre-incubated for $3 \mathrm{~min}$ at $37^{\circ} \mathrm{C}$ was added $0.5 \mathrm{ml}$ of the bacterial suspension $\left(E_{650}=10\right)$. The $\mathrm{pH}$ value of the reaction mixture was previously adjusted with $3 \mathrm{M}-\mathrm{NaOH}$ to become a desired value when mixed with the suspension. After an appropriate reaction period at $37^{\circ} \mathrm{C}, \mathrm{I} \mathrm{ml}$ of the suspension was removed and filtered through a Millipore filter (grade HA). The organisms on the filter membrane were washed three times with $2 \mathrm{ml}$ of the reaction mixture from which ${ }^{\mathrm{I}}{ }^{14} \mathrm{C}$ labelled AIB or [U-14 C]glucose was omitted. The reaction mixture used for washing had the same $\mathrm{pH}$ value as that at which the reaction was carried out. The cells with the membrane were dried overnight in a desiccator, and the radioactivity of the bacteria suspended in $\mathrm{I} 5 \mathrm{ml}$ of the scintillation fluid (4 g PPO and $0 . \mathrm{I} \mathrm{g}$ POPOP in I 1 of a mixture of $45 \%, \mathrm{v} / \mathrm{v}$, methyl cellosolve and $55 \%$, v/v, toluene) was measured.

Chemicals. Polypeptone and meat extract were purchased from Wako Pure Chemical Industries (Tokyo); yeast extract from Kyokuto Seiyaku Co. (Tokyo); vitamin-free Casamino acids from Nissui Sieyaku Co. (Tokyo); and L-amino acids from Ajinomoto Co. (Tokyo). Deoxyribonuclease and NADH were purchased from Sigma and lysozyme from Seikagaku Co. (Tokyo). Radioisotope-labelled compounds were all purchased from Daiichi Pure Chemicals Co. (Tokyo). Other chemicals were reagent grade.

\section{RESULTS}

\section{Morphological and physiological characteristics of the isolate}

The isolate was an aerobic, sporeforming (oval, central spores), Gram-positive, motile and rod-shaped bacterium ( 0.5 to $0.6 \mu \mathrm{m} \times 2$ to $3.5 \mu \mathrm{m}$ ). The GC content of the DNA of the isolate was $42 \cdot 8 \%$. The isolate therefore belongs to the genus Bacillus (Bergey's Manual of Determinative Bacteriology 1957; Smith, Gordon \& Clark, 1952; Normore, 1973). The characteristic feature of the isolate was that the organism grew well in alkaline media and that the growth rate was best at $\mathrm{pH}$ I0.0 to 10.5 . The growth rate was slight or zero at 


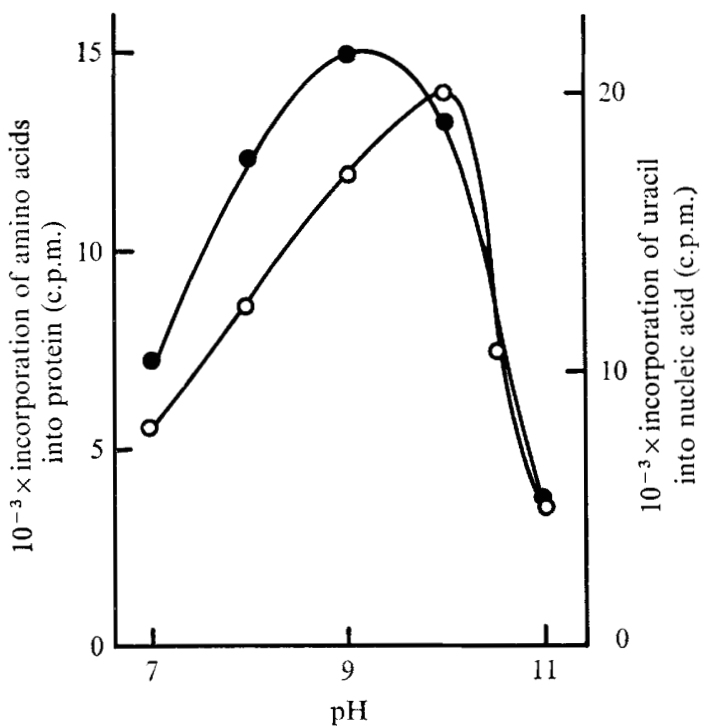

Fig. I

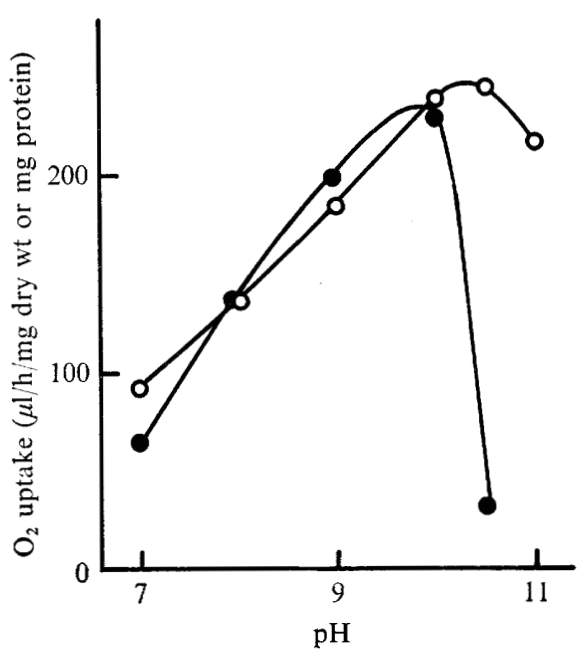

Fig. 2

Fig. I. Incorporation of $(\mathrm{O}){ }^{14} \mathrm{C}$-labelled amino acids or (O) $\left[{ }^{14} \mathrm{C}\right]$ uracil into an alkalophilic bacterium at different $\mathrm{pH}$ values.

Fig. 2. Oxygen consumption of intact bacteria or protoplasts of an alkalophilic bacterium at different $\mathrm{pH}$ values. $O$, Intact bacteria with a culture medium;, protoplasts with a culture medium containing $0.2 \mathrm{M}$-sucrose. The activities were expressed in $\mu \mathrm{l} \mathrm{O}_{2} / \mathrm{h} / \mathrm{mg}$ dry wt $(\mathrm{O})$, or $\mu 1 \mathrm{O}_{2} / \mathrm{h} / \mathrm{mg}$ protein (O).

$\mathrm{pH} 7$ to 8 . The temperature range at $\mathrm{pH} 10.5$ was 15 to $45^{\circ} \mathrm{C}$, and optimum temperature was 35 to $40^{\circ} \mathrm{C}$. The bacterium ( $\mathrm{pH}$ 10 to $10.5 ; 37^{\circ} \mathrm{C}$ ) produced nitrites from nitrates, hydrolysed starch and gelatin, and was catalase positive. The organism did not produce $\mathrm{H}_{2} \mathrm{~S}$ and was Voges-Proskauer negative.

\section{The $\mathrm{pH}$ dependencies of physiological activities of the isolate}

The growth rate of the isolate was maximum at $\mathrm{pH} 10.0$ to 10.5 . Some physiological activities, such as synthesis of protein and nucleic acid, and oxygen consumption in the culture medium of intact bacteria may therefore be expected to be maximum also in this $\mathrm{pH}$ region.

The rate of protein or nucleic acid synthesis was estimated by the incorporation of ${ }^{14} \mathrm{C}$-labelled amino acids or $\left[{ }^{14} \mathrm{C}\right]$ uracil into the TCA-insoluble fraction. The incorporation of amino acid into protein proceeded at a linear rate for about $20 \mathrm{~min}$ of incubation at either $\mathrm{pH} 7.0$ or 10.0. The radioactivities of the bacteria incubated for $5 \mathrm{~min}$ were then measured at different $\mathrm{pH}$ values. The rate of incorporation of uracil into nucleic acid was linear for at least $3 \mathrm{~min}$ of incubation at either $\mathrm{pH} 7 \cdot 0$ or $10 \cdot 0$. The experiments at different $\mathrm{pH}$ values were then carried out with the organisms incubated for $3 \mathrm{~min}$. The activity of protein or nucleic acid synthesis of the bacterium was maximum at about $\mathrm{pH}$ Io, or $\mathrm{pH} 9 \cdot 0$ to $9 \cdot 5$, respectively (Fig. I).

The bacteria suspended in $0.1 \mathrm{M}$-phosphate buffer containing $0.9 \%(\mathrm{w} / \mathrm{v}) \mathrm{NaCl}$ consumed oxygen appreciably (20 to $30 \mu \mathrm{l} \mathrm{O} / \mathrm{h} / \mathrm{mg}$ dry wt organisms), and the rate of oxygen consumption was almost the same in the $\mathrm{pH}_{7}$ to 10.5 region. When the bacteria were suspended in the culture medium, increased oxygen consumption occurred and the activity was maximum at $\mathrm{pH}$ I0.0 to 10.5 (Fig. 2). The protoplast sample in $20 \mathrm{mM}$-phosphate buffer containing Io mM- $\mathrm{MgCl}_{2}$ and $0.2 \mathrm{M}$-sucrose exhibited no oxygen consumption in the $\mathrm{pH} 7$ to 


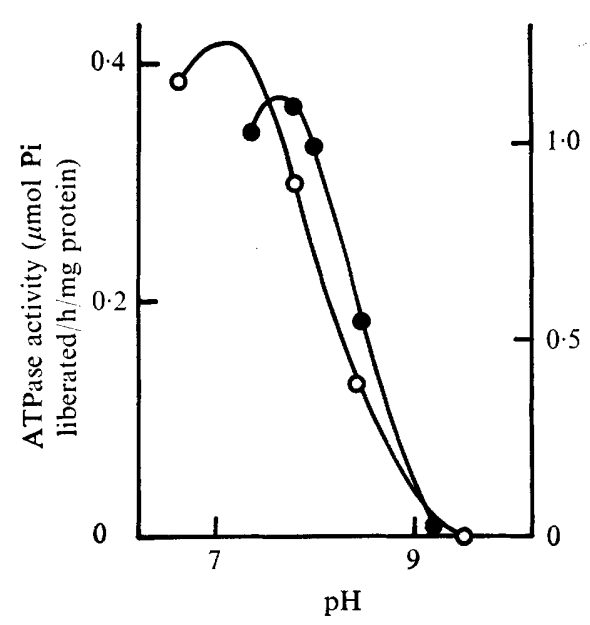

Fig. 3

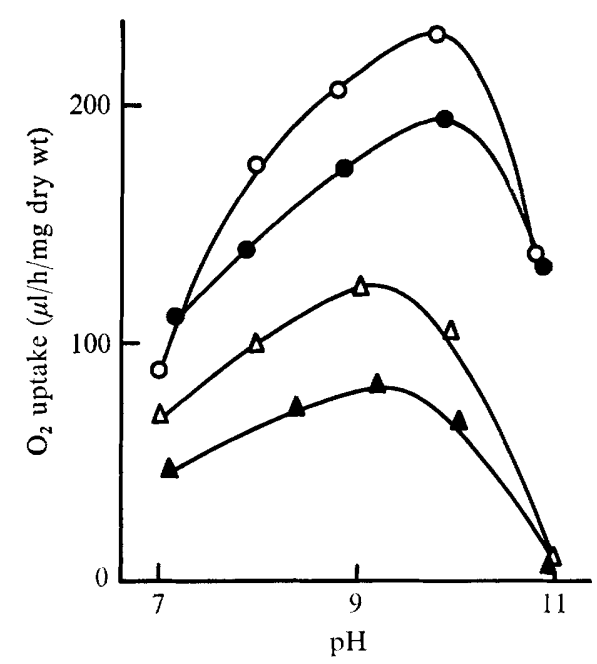

Fig. 4

Fig. 3. Activities of $(O)$ ATPase of the membrane, and $(0)$ L-alanine dehydogenase in the soluble fraction of an alkalophilic bacterium at different $\mathrm{pH}$ values.

Fig. 4. Oxygen consumption of an alkalophilic bacterium with amino acids at different $\mathrm{pH}$ values. $O$, Casamino acids; $\boldsymbol{\theta}$, alanine; $\triangle$, serine; $\boldsymbol{\Delta}$, glutamic acid.

10.5 region. When suspended in the culture medium containing $0.2 \mathrm{M}$-sucrose, the protoplasts consumed oxygen rapidly, and the activity was also maximum at $\mathrm{pH}$ io.

When NADH was added to the membrane fraction, oxygen was consumed rapidly. The activity was maximum at $\mathrm{pH} 7.5$ ( $120 \mu \mathrm{l} \mathrm{O}_{2} / \mathrm{h} / \mathrm{mg}$ protein) and no activity was observed at $\mathrm{pH}$ 10. The ATPase bound to the membrane also exhibited maximum activity at $\mathrm{pH} 7$, and no activity was observed at $\mathrm{pH}$ io (Fig. 3). L-Alanine dehydrogenase in the soluble fraction of the bacteria exhibited maximum activity at $\mathrm{pH} 7.8$ and no activity at $\mathrm{pH}$ io (Fig. 3). L-Lactate and malate dehydrogenases in the soluble fraction exhibited maximum activities at $\mathrm{pH} 7.4$ and 8 ( 50 and $0.15 \mu \mathrm{mol} \mathrm{NADH}$, respectively, oxidized $/ \mathrm{min} / \mathrm{mg}$ protein) and less activity at $\mathrm{pH}$ Iо (I 5 and $0.04 \mu \mathrm{mol} \mathrm{NADH}$, respectively, oxidized $/ \mathrm{min} / \mathrm{mg}$ protein). These results suggest that the intracellular $\mathrm{pH}$ of the bacteria may be about neutral and that the alkalophilic properties of the biochemical reactions of intact bacteria may depend on the membrane function.

\section{The pH dependencies of oxygen consumption of the isolate with various substances}

Although the bacteria suspended in $0 . \mathrm{I}$ M-phosphate buffer $(\mathrm{pH}$ I0.0) containing $0.9 \%$ (w/v) $\mathrm{NaCl}$ consumed oxygen ( 20 to $30 \mu \mathrm{l} \mathrm{O} / \mathrm{h} / \mathrm{mg}$ dry wt), addition of glucose (O.I M) increased this by 90 to $100 \mu 1 \mathrm{O}_{2} / \mathrm{h} / \mathrm{mg}$ dry wt organisms. Addition of other carbohydrates such as fructose and glycerol also increased oxygen consumption by 80 to 90 and by 60 to $70 \mu \mathrm{l} \mathrm{O}_{2} / \mathrm{h} / \mathrm{mg}$ dry wt, respectively. Addition of $0.3 \%$ (w/v) Casamino acids increased the oxygen consumption to 220 to $240 \mu \mathrm{l} \mathrm{O} / \mathrm{h} / \mathrm{mg}$ dry wt, more than did carbohydrates. The oxygen consumption of the bacterium with individual amino acids was examined at $\mathrm{pH} 10 \cdot 0$. Alanine caused most active oxygen consumption (190 to $200 \mu \mathrm{l} \mathrm{O}_{2} / \mathrm{h} / \mathrm{mg}$ dry wt) while serine, glutamic acid and threonine (I 20 to $\mathrm{I} 30,80$ to 90 and 80 to $90 \mu \mathrm{l} \mathrm{O} / \mathrm{h} / \mathrm{mg}$ dry wt, respectively) were less effective. Little or no oxygen consumption was observed with other amino acids, including proline, valine, leucine, glycine, aspartic acid, histidine, arginine, 


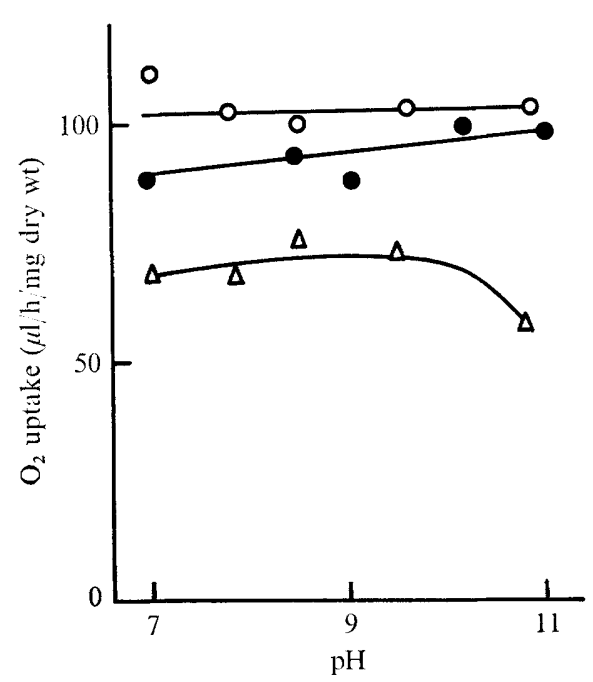

Fig. 5

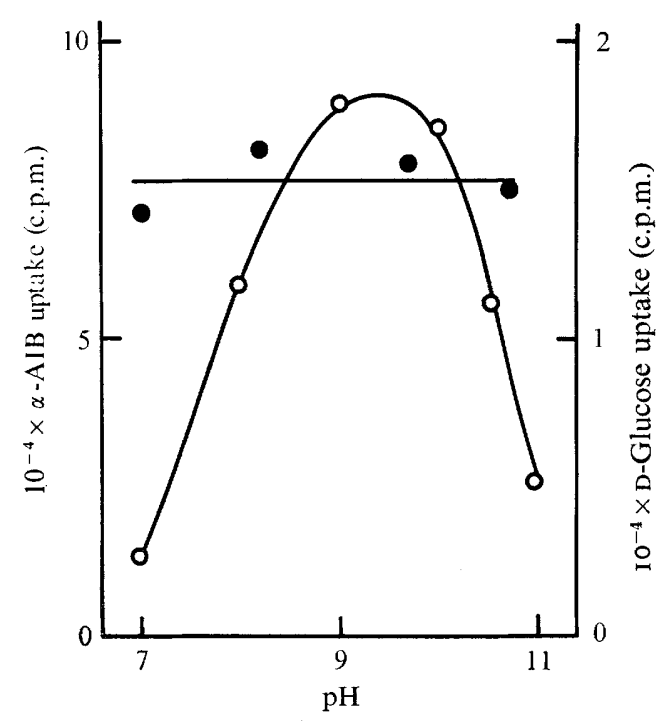

Fig. 6

Fig. 5. Oxygen consumption of an alkalophilic bacterium with carbohydrates at different pH values. $O$, Glucose;, fructose; $\triangle$, glycerol.

Fig. 6. Uptake of $(\mathrm{O}){ }^{14} \mathrm{C}$-labelled AIB or,$\left[\mathrm{U}-{ }^{14} \mathrm{C}\right]$ glucose into an alkalophilic bacterium at different $\mathrm{pH}$ values.

methionine, tryptophan, phenylalanine and lysine. The oxygen consumption of the bacterium on addition of glucose or alanine was 60 and $80 \%$ inhibited respectively, by $10^{-2} \mathrm{M}-\mathrm{KCN}$ and $90 \%$ inhibited by $10^{-2} \mathrm{M}$-amytal. This suggests that the observed oxygen consumption of the bacterium on addition of carbohydrates or amino acids may be mainly due to electron transport from these substances.

When alanine, serine or glutamic acid (or glucose, or fructose) was added to the extract of the bacteria, oxygen consumption was observed only with alanine. Part of the oxygen consumption of intact bacteria observed with alanine may be due to alanine oxidase. The extract exhibited alanine dehydrogenase activity. The oxygen consumption of intact organisms, when alanine or glutamic acid was used as substrate, may be due to electron transport from the keto acids derived from the amino acids by L-amino acid dehydrogenase (or individual amino acid dehydrogenases). The alanine oxidation (alanine oxidase) and dehydrogenation (alanine or L-amino acid dehydrogenase) activities of the bacterium were both found in the soluble fraction, and the activities were maximum at $\mathrm{pH} 8\left(8 \mu 1 \mathrm{O}_{2} / \mathrm{h} / \mathrm{mg}\right.$ protein and $\mathrm{I} \cdot \mathrm{I}$ $\mu$ mol NADH oxidized $/ \mathrm{min} / \mathrm{mg}$ protein, respectively). The enzymes exhibited no activity at $\mathrm{pH}$ iо. The results may also suggest the alkalophilicity of the membrane function.

The bacterium exhibited a maximum oxygen consumption at $\mathrm{pH} 9$ to $\mathrm{IO}$ in the presence of either Casamino acids, alanine, serine or glutamic acid (Fig. 4). The rate of oxygen consumption of the bacterium on addition of glucose, fructose or glycerol, on the other hand, did not vary in the $\mathrm{pH}_{7}$ to $\mathrm{I}$ I region (Fig. 5). The oxygen consumption of the bacterium on addition of pyruvate at $\mathrm{pH} 10 \cdot 0(60$ to $80 \mu \mathrm{l} \mathrm{O} / \mathrm{h} / \mathrm{mg}$ dry wt) was higher than that at $\mathrm{pH} 7 \cdot 0$ (20 to $30 \mu 1 \mathrm{O}_{2} / \mathrm{h} / \mathrm{mg}$ dry wt). These results suggest that the alkalophilic properties of the bacterium may be related not only to the function of the membrane, but also to the charges of the substances that serve as substrates for biological reactions after entering the organisms across the membrane. The permease enzymes for amino acids (and uracil) may require high $\mathrm{pH}$ values. 


\section{The effect of $\mathrm{pH}$ on the transport of substances into bacteria}

The rate of uptake of ${ }^{14} \mathrm{C}$-labelled AIB into organisms at $\mathrm{pH} 7.5$ or ${ }^{10} \cdot 0$ was almost linear for about $7 \mathrm{~min}$ of incubation. The rates of AIB uptake at different $\mathrm{pH}$ values were therefore measured by the radioactivity incorporated into organisms incubated for $5 \mathrm{~min}$. The uptake of AIB was maximum at about pH Io (Fig. 6), as was the protein synthesis from amino acids and oxygen consumption with amino acids as substrates (Figs. I and 4). The uptake of $\left[\mathrm{U}-{ }^{14} \mathrm{C}\right]$ glucose into bacteria at $\mathrm{pH} 7 \cdot 5$ or 10.0 proceeded at a linear rate for about $\mathrm{I}$ min of incubation. The glucose uptake at different $\mathrm{pH}$ values were therefore measured after I min incubation. The rates of glucose uptake by the bacterium were unchanged in the $\mathrm{pH}$ region 8 to Io, although the rate was slightly less at $\mathrm{pH} 7$ or I I than that at $\mathrm{pH} 8$ to Io (Fig. 6). Such a non-alkalophilic property of the bacterium had also been observed for oxygen consumption of the organism on addition of carbohydrates (Fig. 5). Possibly the bacterium exhibits the alkalophilic property only when charged substances cross the membrane.

The oxygen consumption of the bacterium with glucose or Casamino acids at $\mathrm{pH} 10.5$ was saturated at $0.1 \mathrm{M}$ or at $0.3 \%(\mathrm{w} / \mathrm{v})$, respectively. When $0 . \mathrm{I}$ M-glucose and $0.3 \%(\mathrm{w} / \mathrm{v})$ Casamino acids were added together to the suspension of organisms ( $\mathrm{pH}$ 10.5), the oxygen consumption $(290 \mu \mathrm{l} \mathrm{O} / \mathrm{h} / \mathrm{mg}$ dry wt organisms) was the sum of the values with glucose (95 $\mu 1 \mathrm{O}_{2} / \mathrm{h} / \mathrm{mg}$ dry wt) and with Casamino acids $\left(200 \mu 1 \mathrm{O}_{2} / \mathrm{h} / \mathrm{mg}\right.$ dry wt). This suggests that the entrance of glucose and amino acids may take place independently.

\section{Alkalostable property of the isolate}

Oxygen consumption by suspension of organisms in $O \cdot I$ M-phosphate buffer containing $0.9 \%(\mathrm{w} / \mathrm{v}) \mathrm{NaCl}$ was measured at $\mathrm{pH}$ I0.0 $\left(37^{\circ} \mathrm{C}\right)$ without added glucose or Casamino acids. In this case, oxygen consumption was linear for at least $\mathrm{I} 5$ to $20 \mathrm{~min}$ following about Io min of pre-incubation for temperature equilibration. This suggests that the oxidation system may be stable at $\mathrm{pH} 10 \cdot 0$ for at least 30 min under these conditions.

When the suspension in phosphate buffer $\left(E_{650}=10\right)$ was incubated at $\mathrm{pH} 7.5$ or 10.0 for $3 \mathrm{~h}$ at $37^{\circ} \mathrm{C}$, the oxygen consumption with Casamino acids had decreased to $70 \%$ or to $20 \%$ of the original activity, respectively. When the bacterium was incubated at $\mathrm{pH}$ i 0.0 for $3 \mathrm{~h}$ with $0 . \mathrm{I} \mathrm{M}$-glucose or $30 \mathrm{~mm}$-alanine, however, the activity only decreasd to 70 or $90 \%$, respectively. As suggested for an acidophilic thermophilic bacterium (Yamazaki, Koyama \& Nosoh, 1973), the alkalophilic bacterium may also have an energy-dependent mechanism for an $\mathrm{OH}^{-}$exclusion mechanism functioning on the membrane. An investigation with such an approach is now being attempted.

\section{DISCUSSION}

Many cultures of alkalophilic bacteria related to the genus Bacillus have recently been isolated, and a variety of exoenzymes has been purified from the bacteria (Horikoshi, I97I $a, b$, 1972; Horikoshi \& Atsukawa, I973a, b; Kurono \& Horikoshi, 1973; Boyer \& Ingle, 1972). Since the bacteria are grown in alkaline culture media (pH 10 to II), it is not surprising that the exoenzymes obtained from the cultures exhibit alkalophilic and alkalostable properties. Alkalophilic bacteria, including our isolate, exhibited maximum growth in alkaline media ( $\mathrm{pH}$ io to II), and biological activities such as the oxygen consumption with amino acids and the protein and nucleic acid syntheses, examined with intact organisms of our isolate, exhibited maximum activities in alkaline environments ( $\mathrm{pH} 9.0$ to I0.5) (Figs. I, 2 and 4 ). The results, however, do not indicate that the biological reactions, including those shown in the Figures, will take place in organisms most actively in this $\mathrm{pH}$ region. As 
deduced from our results (Fig. 3), the intracellular environment of the bacterium may be neutral and the biological reactions occurring internally may exhibit maximum activities in neutral $\mathrm{pH}$. Alanine oxidase and dehydrogenase were located in the soluble fraction of the bacteria, and the enzyme activities were maximum at $\mathrm{pH} 8$ and no activity was observed at $\mathrm{pH}$ io. The alkalophilic property of the oxygen consumption of the bacterium with alanine as substrate, and probably the alkalophilic properties of the organism, in general, may therefore depend on the membrane function of the organisms. The entrance of substances into the bacterium across the membrane (the permease systems) may be considered to be alkalophilic. As shown in Fig. 6, however, not all of the biological reactions of intact bacteria appeared alkalophilic, i.e. the membrane of the bacterium did not seem alkalophilic to all the substances admitted across the membrane. The results (Fig. 6) suggest that the membrane of the bacterium may exhibit the alkalophilic property only when charged substances such as amino acids cross the membrane, but may not show the property in the case of non-charged substances such as glucose, fructose and glycerol.

The authors thank the late Mr H. Ichimura for his kind gift of indigo ball. They are also indebted to the Central Research Laboratories, Ajinomoto Co., for the GC content estimation. This work was supported in part by a grant from the Ministry of Education, Japan.

\section{REFERENCES}

Boyer, E. W. \& INGLE, M. B. (1972). Extracellular alkaline amylase from a Bacillus species. Journal of Bacteriology r10, 992-I000.

Bergey's Manual of Determinative Bacteriology, 7 th edn (1957). Edited by R. S. Breed, E. G. D. Murray and N. R. Smith. London: Ballière, Tindal and Cox.

Hakala, M. T., Glaid, A. J. \& Schwert, G. W. (I956). Lactic dehydrogenase. II. Variation of kinetic and equilibrium constants with temperature. The Journal of Biological Chemistry 221, 19I-209.

Horikoshi, K. ( I97 I $a$ ). Production of alkaline enzymes by alkalophilic microorganisms. I. Alkaline protease produced by Bacillus No. 221. Agricultural and Biological Chemistry 35, 1407-1414.

Horikoshi, K. (197I $b$ ). Production of alkaline enzymes by alkalophilic microorganisms. II. Alkaline amylase produced by Bacillus No. A-40-2. Agricultural and Biological Chemistry 35, 1783-I79I.

HorIKosHI, K. (1972). Production of alkaline enzymes by alkalophilic microorganisms. III. Alkaline pectinase of Bacillus No. P-4-N. Agricultural and Biological Chemistry 36, 285-293.

Horikoshi, K. \& AtsukaWA, Y. (1973a). $\beta$-I,3-Glucanase produced by alkalophilic bacteria, Bacillus No. K-I 2-5. Agricultural and Biological Chemistry 37, 1449-1456.

Horikoshi, K. \& Atsukawa, Y. (I973 $b$ ). Alkaline catalase produced by Bacillus No. Ku-I. Agricultural and Biological Chemistry 37, 2565-2570.

Kurono, Y. \& Horikoshi, K. (I973). Alkaline catalase produced by Bacillus No. Ku-I. Agricultural and Biological Chemistry 37, 2565-2570.

MARMUR, J. A. (I96I). A procedure for the isolation of deoxyribonucleic acid from micro-organisms. Journal of Molecular Biology 3, 208-218.

Marmur, J. A. \& Doty, P. (1962). Determination of the base composition of deoxyribonucleic acid from its thermal denaturation temperature. Journal of Molecular Biology 5, 109-1 18.

Nakao, T., Tashima, Y., Nagano, Y. \& NakaO, M. (I965). Highly specific sodium-potassium activated adenosine triphosphatase from various tissues of rabbit. Biochemical and Biophysical Research Communication 19, 755-758.

NORMORE, W. M. (I973). Guanine-plus-cytosine (GC) composition of the DNA of bacteria, fungi, algae and protozoa. In Handbook of Microbiology vol. 2, p. 585. Edited by A. I. Laskin and H. A. Lechevalier. Ohio: CRC Press.

OchoA, S. (1955). Malic dehydrogenase from pig heart. In Methods in Enzymology, vol, 1, p. 735 . Edited by S. P. Colowick and N. O. Kaplan. New York: Academic Press.

Smith, N. R., Gordon, R. E. \& Clark, F. E. (1952). Aerobic Sporeforming Bacteria. U.S. Department of Agriculture, Agriculture monograph No. 16.

Wiame, J. M., PiÉrard, A. \& Ramos, F. (I962). L-Alanine dehydrogenase from Bacillus subtilis. In Methods in Enzymology, vol. 5, p. 673. Edited by S. P. Colowick and N. O. Kaplan. New York: Academic Press.

YAMAZAKI, Y., Koyama, N. \& NosOH, Y. (1973). On the acidostability of an acidophilic thermophilic bacterium. Biochimica et biophysica acta 3I4, 257-260. 